УдК 636

\title{
ПРОДУКТИВНЫЕ КАЧЕСТВА ПЕРВОТЕЛОК
}

\author{
Алексеева Юлия Анатольевна \\ кандидат сельскохозяйственных наук, доцент \\ Дейч Виктория Юрьевна \\ кандидат экономических наук \\ Ильина Ольга Петровна \\ доктор ветеринарных наук, профессор \\ Дейч Ольга Ивановна \\ кандидат экономических наук, доцент \\ ФГБОУ ВО Иркутский ГАУ \\ им. А.А. Ежевского
}

Аннотация: Стабильный рост производства продуктов животноводства и существенное сокращение их себестоимости достигается в основном за счет увеличения продуктивности и обширного введения интенсивных технологий, основными элементами которых является повышение генетического потенциала животных и обеспечение их достаточным и полноценным кормлением в течение всего года.

Современное состояние молочного скотоводства вызвало ускорения процессов интенсификации отрасли. В связи с этим в стране развернулось массовое скрещивание существующих пород скота со специализированными молочными породами, в частности с голштинской. В современной научной литературе имеются противоречивые данные, полученные при голшитинизации черно-пестрого скота, в частности по уровню молочной продуктивности, воспроизводительным качествам и т.д.[1].

Результаты голштинизации черно-пестрого скота во многих хозяйствах России говорят о значимом превосходстве животных по основным признакам молочной продуктивности. Наши исследования, молочной продуктивности первотелок черно-пестрых помесей превышают черно-пестрых сверстниц в течение всей лактации. Удой молока за лактацию в контрольной группе ниже, чем в опытной на 646.7 кг (Р<0.001), среднее содержание жира ниже на $0.09 \%$, чем в опытной группе $(\mathrm{P}<0.05)$. Максимальное количество молочного жира 
получено в опытной группе - 152.8 кг, что на 25.5 кг больше, чем в контрольной группе $(\mathrm{P}<0.01)$.Содержание белка в молоке контрольной группы выше на $0.02 \%$,чем в опытной группе, а количество молочного белка больше, чем в контрольной на 19.87 кг.

Ключевые слова: Первотелки, молочная продуктивность, содержание жира, содержание белка черно-пестрая порода, черно-пестрые помеси.

\title{
PRODUCTIVE QUALITY OF TRANCHERS
}

\section{Alekseeva Julia A. Deich Victoria Yuryevna Ilina Olga Petrovna Deitch Olga Ivanovna}

\begin{abstract}
Stable growth in the production of livestock products and a significant reduction in their cost is achieved mainly due to increased productivity and the extensive introduction of intensive technologies, the main elements of which are to increase the genetic potential of animals and provide them with sufficient and complete feeding throughout the year.

The current state of dairy cattle breeding has accelerated the processes of intensification of the industry. In this regard, a massive crossbreeding of existing livestock breeds with specialized dairy breeds, in particular Holstein, has unfolded in the country. In the modern scientific literature there are conflicting data obtained during holchitinization of black-motley cattle, in particular on the level of milk productivity, reproductive qualities, etc. [1].

The results of Holstein black-and-white cattle in many Russian farms indicate a significant superiority of animals in terms of the main signs of dairy productivity. Our studies of milk production of black-and-white mixed-bird heifers exceed blackand-white peers throughout lactation. Milk yield for lactation in the control group is lower than in the experimental group by $646.7 \mathrm{~kg}(\mathrm{P}<0.001)$, the average fat content is lower by $0.09 \%$ than in the experimental group $(\mathrm{P}<0.05)$. The maximum amount of milk fat obtained in the experimental group was $152.8 \mathrm{~kg}$, which is 25.5 $\mathrm{kg}$ more than in the control group $(\mathrm{P}<0.01)$. The protein content in the milk of the control group is $0.02 \%$ higher than in the experimental group, and the amount of milk protein more than in the control at $19.87 \mathrm{~kg}$.
\end{abstract}




\section{СОВРЕМЕННЫЕ ИССЛЕДОВАНИЯ КАК ДРАЙВЕР РОСТА ЭКОНОМИКИ И СОЦИАЛЬНОЙ СФЕРЫ}

Key words: Heifers, milk production, fat content, protein content, blackmotley breed, black-motley mixes.

Увеличение продуктивности крупного рогатого скота и производства высококачественных продуктов животноводства является одной из важных проблем сельского хозяйства.

В решении этих задач ведущее место занимает совершенствование племенных и продуктивных качеств животных черно - пестрой породы, разводимой во многих регионах страны[2].

В условиях промышленной технологии производства молока и рыночной экономики ведения молочного скотоводства, к животным предъявляются высокие требования в отношении молочной продуктивности, пригодности вымени к машинному доению, конституциональной крепости, устойчивости к заболеваниям, хорошей воспроизводительной способности и долголетию хозяйственного использования.

В Иркутской области наибольшее распространение возымела чернопестрая порода. Она отлично адаптирована к условиям промышленной технологии изготовления молока, однако в массе недостаточно продуктивна, многие животные не отвечают предъявляемым требованиям к технологическим качествам вымени, крепости конституции, выраженности молочного типа.

Голштинская порода в настоящее время имеет высокий генетический потенциал, по молочной продуктивности и высокую оплату корма, и по функциональным свойствам вымени она превышает все имеющиеся в настоящее время породы молочного скота [3].

Цель исследований - изучение продуктивных качеств первотелок разных генотипов.

Материалы и методы. Работа была проведена в условиях КФХ «Егоров АС». Для проведения опыта были сформированы две группы по 9 голов, первотелок аналогов с учетом возраста, породности, живой массы, упитанности. По общепринятым методикам, на основании ежемесячных доений определяли уровень молочной продуктивности коров. С помощью анализатора молока «Клевер-1 М» определяли массовую долю жира, белка в молоке, плотность, СОМО. Условия содержания и кормления для всех опытных животных были одинаковые. 


\section{СОВРЕМЕННЫЕ ИССЛЕДОВАНИЯ КАК ДРАЙВЕР РОСТА ЭКОНОМИКИ И СОЦИАЛЬНОЙ СФЕРЫ}

Полученные первичные данные обработаны методом вариационной статистики [4].

Результаты и обсуждение. В проведенных нами исследованиях, за период опыта было выявлено, что черно-пестрые помеси превосходят чернопестрых сверстниц в течение всей лактации, данные представлены в табл. 1.

\section{Таблица 1}

Молочная продуктивность опытных групп, $(\overline{X \pm} S \bar{x})$

\begin{tabular}{|c|c|c|}
\hline \multirow{2}{*}{ Месяц лактации } & \multicolumn{2}{|c|}{ Группы животных } \\
\cline { 2 - 3 } & контрольная & опытная \\
\hline 1 месяц & $461.0 \pm 3.88$ & $579.7 \pm 6.21$ \\
\hline 2 месяц & $528.2 \pm 8.44$ & $578.8 \pm 6.25$ \\
\hline 3 месяц & $511.1 \pm 4.46$ & $529.8 \pm 6.46$ \\
\hline 4 месяц & $465.5 \pm 3.60$ & $509.1 \pm 6.19$ \\
\hline 5 месяц & $411.5 \pm 3.28$ & $465.1 \pm 1.89$ \\
\hline 6 месяц & $382.0 \pm 5.31$ & $400.7 \pm 1.98$ \\
\hline 7 месяц & $300.3 \pm 5.33$ & $283.3 \pm 15.16$ \\
\hline 8 месяц & $238.4 \pm 4.31$ & $226.2 \pm 4.32$ \\
\hline 9 месяц & $202.6 \pm 4.12$ & $109.2 \pm 3.09$ \\
\hline 10 месяц & $59.9 \pm 8.05$ & $4207.5 \pm 39.65$ \\
\hline Удой за 10 месяцев & $3560.8 \pm 37.10$ & \\
\hline лактации, кг & & \\
\hline
\end{tabular}

По данным таблицы 1 видно, в первом месяце лактации в опытной группе удой молока составил 461.03 кг это выше, чем в контрольной на 18.7 кг. В шестом месяце количество молока 465.1 кг так же выше, чем в контрольной группе. Удой молока за лактацию в опытной группе составил $4207.5 \pm 39.65$, а к контрольной группе $3560.8 \pm 37.10$, что на 646.7 кг выше.

Многие ученые [5,6] для изучения закономерностей течения лактационного процесса строили графики лактационных кривых. 


\section{СОВРЕМЕННЫЕ ИССЛЕДОВАНИЯ КАК ДРАЙВЕР РОСТА ЭКОНОМИКИ И СОЦИАЛЬНОЙ СФЕРЫ}

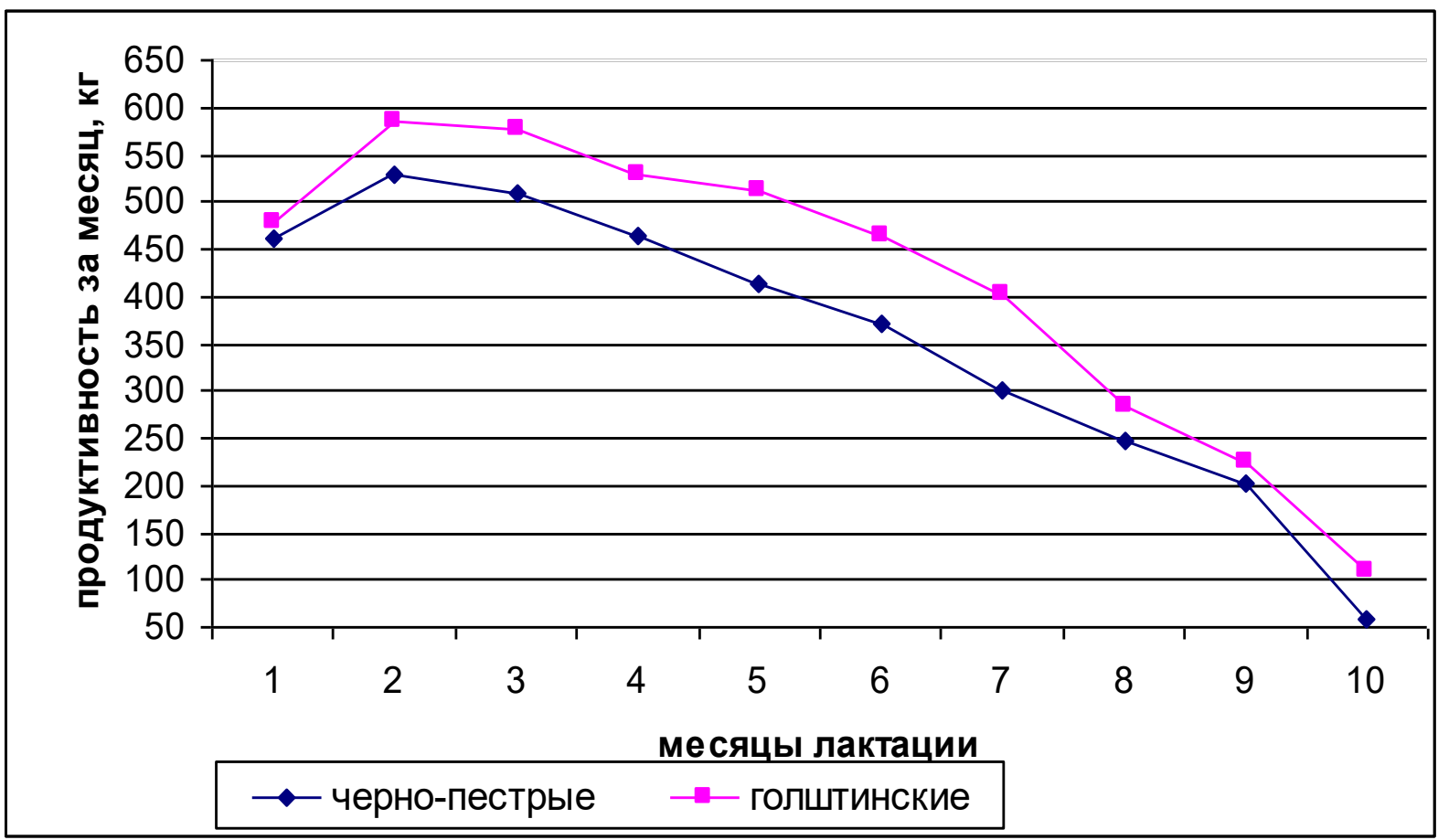

Рис. 1. Лактационная кривая

Установлено, что надой на протяжении лактации колеблется: после отела некоторое время увеличивается, потом, достигнув максимума, начинает равномерно понижается. По рисунку видно, у всех животных отмечен наивысший удой на втором месяце лактации. На протяжении остального времени наблюдалось градационное снижение. Анализ лактационных кривых позволил отнести исследуемых первотелок по классификации к первому типу (высшая устойчивая лактационная деятельность).

От генетических особенностей зависит качественный состав молока, по данным многочисленных исследований[7,8,9].

Состав молока черно-пестрых помесей изучен рядом ученых. Помесные животные значительно превосходят своих сверстниц по содержанию сухого вещества [10]. Химический состав молока представлен в таблице 2. 


\section{СОВРЕМЕННЫЕ ИССЛЕДОВАНИЯ КАК ДРАЙВЕР РОСТА ЭКОНОМИКИ И СОЦИАЛЬНОЙ СФЕРЫ}

Таблица 2

Химический состав молока опытных групп, $(\overline{X \pm} S \bar{x})$

\begin{tabular}{|l|c|c|}
\hline \multirow{2}{*}{ Показатель } & \multicolumn{2}{|c|}{ Группа животных } \\
\cline { 2 - 3 } & контрольная & опытная \\
\hline Удой за лактацию, кг & $3560.8 \pm 37.10$ & $4207.5 \pm 39.65$ \\
\hline Содержание жира, \% & $3.59 \pm 0.03$ & $3.68 \pm 0.05^{*}$ \\
\hline Количество молочного жира, кг & $127.21 \pm 2.09$ & $152.82 \pm 7.07^{* *}$ \\
\hline Содержание белка, \% & $3.40 \pm 0.04$ & $3.38 \pm 0.03$ \\
\hline Количество молочного белка, кг & $121.35 \pm 3.60$ & $141.22 \pm 3.70$ \\
\hline Массовая доля сухого вещества, \% & $11.94 \pm 0.03$ & $12.33 \pm 0.22$ \\
\hline Количество сухого вещества, кг & 425.42 & 513.53 \\
\hline Массовая доля СОМО, \% & 8.36 & 8.62 \\
\hline Количество СОМО, кг & 297.28 & 359.72 \\
\hline Плотность молока, кг $/{ }^{3}$ & $1028.2 \pm 0.07$ & $1028.32 \pm 0.08$ \\
\hline
\end{tabular}

Примечание: * $(\mathrm{P}<0,05),{ }^{* * *}(\mathrm{P}<0,01),{ }^{* * * *}(\mathrm{P}<0,001)$ *

По данным таблицы 2 видно, что удой за лактацию в опытной группе выше на 646.7 кг, чем в контрольной, содержание жира составило соответственно $3.86 \%$ это на $0.08 \%$ ниже, чем в контрольной группе. Для оценки по жирномолочности количество молочного жира в опытной группе составило 152.82 кг, это на 25.5 кг больше, чем в контрольной группе. Количество белка и молочного белка выше в опытной группе на $0.02 \%-19.7$ кг соответственно. Показатель плотности молока находился в допустимых пределах и составил 1028 кг/ $\mathrm{cm}^{3}$.

В результате проведенных исследований можно заключить, что животные опытной группы в первую лактацию показали хорошие результаты по молочной продуктивности.

\section{Список литературы}

1. Прохоренко П.Н. Голштино-фризская порода скота / П.Н. Прохоренко, Ж.Г. Логинов. - Л.: Агропромиздат, 1986. - 238c. 


\section{СОВРЕМЕННЫЕ ИССЛЕДОВАНИЯ КАК ДРАЙВЕР РОСТА ЭКОНОМИКИ И СОЦИАЛЬНОЙ СФЕРЫ}

2. Сеин О.Б Продуктивное использование черно-пестрый голштинских помесей/ О.Б. Сеин, Н.И. Жеребилов, Л.И. Кибкало, Н.Д. Родина// Зоотехния. - 2005. - № 2. - C. 3-5

3. Шадрин С.В. Продуктивные и биологические признаки черно-пестро голштинских помесей разной кровности в условиях Красноярского края: Автореф. дис. канд. с.-х. наук: 06.02.01/С.В. Шадрин. Красноярск. 2002. - 22с.

4. Коростелева Н. И. Биометрия в животноводстве: учебное пособие / Н. И. Коростелева [и др.]. // Барнаул: Изд-во АГАУ. - 2009. - 210с.

5. Миннебаев М. Молочная продуктивность первотелок разной кровности // Молочное и мясное скотоводство. - 2008. - №6. - С.35-36

6. Попов Н. Генетическая и генеологическая однородность стад чернопестрой породы / Попов Н., Уливанова Г., Ахмедова Т. // Молочное и мясное скотоводство. - 2002. - №4. - С.22-24

7. Голубков А.И. Повышение продуктивности коров красно-пестрой породы в Красноярском крае / Голубков А.И. // Современное состояние и перспективы совершенствования пород сельскохозяйственных животных в Сибири: Сб. докл. сиб. науч.-практич. конф. - Красноярск, 2006. - С. 21-30.

8. Кузякина Л.И. Изменения экстерьера и продуктивности коров чернопестрой породы при голштинизации стад / Кузякина Л.И. // Зоотехния. - 2005. - C.12-13.

9. Эрнст Л.К. Физиологические и иммунологические показатели голшитнизированного сибирского типа черно-пестрого скота / Л.К Эрнст, А.И. Желтиков, В.П. Петухов //Докл. Россельхозакадемии. 1991. - № 6.- С.35.

10. Любимов А. Состав и свойства молока помесных коров / Любимов А., Сергеева В. // Молочное и мясное скотоводство. - 2007. №3. - С. 34-36 